\title{
Role of insulin-like growth factor-1 and growth hormone in growth inhibition induced by magnesium and zinc deficiencies
}

\author{
BY INGE DøRUP, ALLAN FLYVBJERG, MARIA E. EVERTS \\ AND TORBEN CLAUSEN \\ Institute of Physiology, University of Aarhus and Medical Department $M$ (Diabetes and \\ Endocrinology), Aarhus Kommunehospital, DK-8000 Aarhus C, Denmark
}

(Received 10 September 1990 - Accepted 25 February 199I)

\begin{abstract}
Nutritional deficiencies of magnesium or zinc lead to a progressive and often marked growth retardation. We have evaluated the effect of $\mathrm{Mg}$ and $\mathrm{Zn}$ deficiency on growth, serum insulin-like growth factor-1 (sIGF-1), growth hormone (s-GH) and insulin (s-insulin) in young rats. In 3-week-old rats maintained on Mg-deficient fodder for $12 \mathrm{~d}$ the weight gain was reduced by about $34 \%$, compared with pair-fed controls. This was accompanied by a $44 \%$ reduction in s-IGF-1, while s-insulin showed no decrease. After 3 weeks on Mg-deficient fodder, growth had ceased while serum Mg (s-Mg) and s-IGF-1 were reduced by 76 and $60 \%$ respectively. Following repletion with $\mathrm{Mg}$, s-Mg was completely normalized in 1 week, and s-IGF-1 reached control level after 2 weeks. Growth rate increased, but the rats had failed to catch up fully in weight after 3.5 weeks. Absolute and relative pair-feeding were compared during a $\mathbf{M g}$ repletion experiment. Absolute pair-fed animals were given the same absolute amount of fodder as the Mg-deficient rats had consumed the day before. Relative pair-fed animals were given the same amount of fodder, on a body-weight basis, consumed in the Mg-deficient group the day before. In a repletion experiment the two methods did not differ significantly from each other with respect to body-weight, muscle weight, tibia length and s-IGF-1, although there was a tendency towards higher levels in the relative pair-fed group. The peak in s-GH after growth hormone-releasing factor 40 (GRF 40) was 336 ( $\mathrm{SE}$ 63) $\mu \mathrm{g} / \mathrm{l}$ in 5-week-old rats that had been $\mathrm{Mg}$ depleted for $14 \mathrm{~d}$, whereas age-matched control animals showed a peak of 363 (SE 54) $\mu \mathrm{g} / \mathrm{l}$ (not significant).

In 3-week-old rats maintained on $\mathrm{Zn}$-deficient fodder for $14 \mathrm{~d}$ weight gain was reduced by $83 \%$ compared with pair-fed controls. Serum $\mathrm{Zn}(\mathrm{s}-\mathrm{Zn})$ and s-IGF-1 were reduced by 80 and $69 \%$ respectively, while s-insulin was reduced by $66 \%$. The $\mathrm{Zn}$-deficient animals showed a more pronounced growth inhibition than that seen during $\mathrm{Mg}$ deficiency and after $17 \mathrm{~d}$ on $\mathrm{Zn}$-deficient fodder s-IGF-1 was reduced by $83 \%$. Following repletion with $\mathrm{Zn}, \mathrm{s}-\mathrm{Zn}$ was normalized and s-IGF-1 had increased by $194 \%$ ( $P$ $<0.05$ ) after $3 \mathrm{~d}$. s-IGF-1, however, was not normalized until after 2.5 weeks of repletion. Growth rate increased but the catch-up in weight was not complete during 6 weeks. The maximum increase in s-GH after GRF 40 was 774 (SE 61) $\mu \mathrm{g} / \mathrm{l}$ in control animals $v .657$ (SE 90) $\mu \mathrm{g} / \mathrm{l}$ in 6-week-old rats that had been $\mathrm{Zn}$-depleted for $12 \mathrm{~d}$ (not significant). In conclusion, both $\mathrm{Mg}$ and $\mathrm{Zn}$ deficiency lead to growth inhibition that is accompanied by reduced circulating s-IGF-1, but unchanged s-GH response. $\mathrm{Zn}$ deficiency, but not Mg deficiency, caused a reduction in s-insulin. The reduction in S-IGF-1 could not be attributed to reduced energy intake, but seems to be a specific effect of nutritional deficiency of $\mathrm{Mg}$ or $\mathrm{Zn}$. It is suggested that the growth retardation seen during these deficiency states may be mediated through reduced s-IGF-1 production.
\end{abstract}

Growth: Magnesium deficiency: Zinc deficiency: Insulin-like growth factor 1: Growth hormone: Rat

It is well recognized that nutritional deficiency of either magnesium or zinc interferes with growth in animals (Schwartz et al. 1970; Williams \& Mills, 1970; Hunt, 1971) as well as in children (Caddell \& Goddard, 1967; Golden, 1988). Insufficient supplies of Mg or Zn lead to a marked reduction in weight gain, which is reversible following repletion. In rats, 
reduced dietary intake of $\mathrm{Mg}$ or $\mathrm{Zn}$ leads to a rapid and pronounced decrease in the serum levels (Hurley, 1969; Hunt, 1971), whereas little or no change in the concentrations of either element in skeletal muscle can be detected (Miller, 1969; Hunt, 1971; O'Leary et al. 1979; Dørup \& Clausen, 1991). Therefore the impairment of growth cannot readily be accounted for as the result of reduced availability of $\mathrm{Mg}$ or $\mathrm{Zn}$ in the major pools of proteinsynthesizing cells. This suggests that insufficient supplies of $\mathrm{Mg}$ or $\mathrm{Zn}$ influence growth via endocrine regulatory systems.

Earlier studies performed in our laboratory have shown that when rats are maintained on potassium-deficient fodder, growth and protein synthesis are significantly inhibited even before muscle $\mathrm{K}$ shows any significant reduction (Dørup \& Clausen, 1989). This downregulation was found to be associated with reduced serum levels of insulin-like growth factor-1 (s-IGF-1) and growth hormone (s-GH) (Flyvbjerg et al. 1991).

In analogy, it has been reported that $\mathrm{Zn}$ deficiency causes a reduction in serum somatomedin C (s-IGF-1), as determined by radioimmunoassay (Cossack, 1984; Öner et al. 1984) or somatomedin activity as determined by bioassay (Bolze et al. 1987). To our knowledge, however, no studies have explored whether the growth inhibition seen with restricted dietary supply of $\mathrm{Mg}$ is associated with changes in the levels of s-IGF-1 and s-GH.

The present study was performed to evaluate the levels of s-GH, s-IGF-1 and s-insulin during dietary $\mathrm{Mg}$ and $\mathrm{Zn}$ deficiency. Furthermore, these variables were compared to changes in growth and the serum concentrations of $\mathrm{Mg}$ or $\mathrm{Zn}$. In a parallel study the changes in the in vivo protein synthesis and tissue contents were analysed (Dørup \& Clausen, 1991).

\section{MATERIALS AND METHODS}

Animals and treatment

All experiments were performed using female Wistar rats 3-4 weeks old at the start of the experiment. The animals were kept at constant temperature $\left(23^{\circ}\right)$, humidity $(53 \%)$ and daylength $(12 \mathrm{~h})$. Stainless-steel frames were positioned in the bottom of the cages to prevent the animals from having access to urine or faeces. Until used for experiments, all rats were maintained on a standard fodder containing $60 \mathrm{mmol} \mathrm{Mg} / \mathrm{kg}$ and $500 \mu \mathrm{mol}$ $\mathrm{Zn} / \mathrm{kg}$ (Altromin, Lage, Germany). Since it is known that s-IGF-1 increases considerably with age (Handelsman et al. 1987), at the start of each experiment the experimental and control animals were carefully matched with respect to age and weight. Experiments were performed with semi-synthetic $\mathrm{Mg}$-free or $\mathrm{Zn}$-free fodder (EWOS, Södertälje, Sweden). This fodder had an energy content of $14.0 \mathrm{~kJ}(3.35 \mathrm{kcal}) / \mathrm{g}$ and contained $(\mathrm{g} / \mathrm{kg}) 170$ protein, $70 \mathrm{fat}, 644$ carbohydrates, 50 vitamins and minerals, and water content was $66 \mathrm{~g} / \mathrm{kg}$.

$\mathrm{Mg}$ deficiency was induced by maintaining rats on distilled water and a semi-synthetic $\mathrm{Mg}$-deficient fodder. The mean $\mathrm{Mg}$ content of all batches of this fodder was 1.56 (SE 0.07) $\mathrm{mmol} / \mathrm{kg}$. With the exception of the pair-feeding experiments (see p. 507) control animals were maintained on distilled water and the same fodder supplemented with magnesium chloride to give a final concentration of $50 \mathrm{mmol} \mathrm{Mg} / \mathrm{kg}$. This is well above the minimum dietary requirement for $\mathrm{Mg}$ which is considered to be $17 \mathrm{mmol} / \mathrm{kg}$ (Warner \& Breuer, 1972).

Before the start of the dietary regimen the rats were acclimatized to the semi-synthetic fodder by feeding the $\mathrm{Mg}$-supplemented fodder for $3 \mathrm{~d}$. After this adjustment period the rats were randomly divided into the experimental groups.

$\mathrm{Mg}$ repletion after a depletion period was done in one type of experiment by giving the $\mathrm{Mg}$-depleted animals free access to $\mathrm{Mg}$-enriched fodder $(50 \mathrm{mmol} \mathrm{Mg} / \mathrm{kg})$, while in another type of experiment the depleted animals had restricted access to fodder (see p. 507).

Graded $\mathrm{Mg}$ deficiencies were induced by maintaining the animals on distilled water and 
$\mathrm{Mg}$-deficient fodder supplemented with $\mathrm{MgCl}_{2}$ to various contents between 2 and $15 \mathrm{mmol} \mathrm{Mg} / \mathrm{kg}$. Age-matched control rats were maintained on $\mathrm{Mg}$-deficient fodder supplemented with $\mathrm{MgCl}_{2}$ to a final concentration of $50 \mathrm{mmol} \mathrm{Mg} / \mathrm{kg}$.

Pair-feeding experiments were performed on 3-week-old rats during both $\mathrm{Mg}$ depletion and $\mathrm{Mg}$ repletion. In the first instance the control animals received the same amount of fodder, as a percentage of body weight, as that consumed by the rats on Mg-deficient fodder during the previous $24 \mathrm{~h}$. The daily food supply was established each morning after assessment (by weighing uneaten fodder) of the food consumed by the $\mathrm{Mg}$-depleted group during the previous $24 \mathrm{~h}$. The pair-fed animals were then each given the same amount of fodder, on a body-weight basis, as that consumed by the Mg-depleted group (relative pairfeeding). In addition, an ad lib.-fed group with free access to fodder was included. All three groups were kept on $\mathrm{Mg}$-free fodder and the $\mathrm{Mg}$-depleted group received distilled water while pair-fed and ad lib.-fed animals were given access to a $\mathrm{MgCl}_{2}$ solution $(40 \mathrm{mmol} / \mathrm{l})$.

In the second pair-feeding experiment, twenty-three animals were kept on the $\mathrm{Mg}$ deficient fodder and distilled water for $17 \mathrm{~d}$. Fodder consumption was measured for the last $5 \mathrm{~d}$. Then the animals were randomized into three groups: one group remained on distilled water and the Mg-deficient diet (Mg-depleted), another group received the same absolute amount of fodder as consumed by the $\mathrm{Mg}$-deficient group the preceding day plus a $\mathrm{MgCl}_{2}$ solution ( $40 \mathrm{mmol} / \mathrm{l}$ ) (repleted by absolute pair-feeding), and the third group received the same amount of fodder, on a body-weight basis, as that consumed in the $\mathrm{Mg}$-deficient group the preceding day plus a $\mathrm{MgCl}_{2}$-solution $(40 \mathrm{mmol} / \mathrm{l}$ ) (repleted by relative pairfeeding).

The animals were decapitated, the muscles rapidly excised, immediately frozen in liquid nitrogen and weighed. The tibia was dissected free from connective tissue and length was measured by a slide gauge.

$\mathrm{Zn}$ deficiency was induced by maintaining rats on distilled water and a semi-synthetic $\mathrm{Zn}$ free fodder. The mean $\mathrm{Zn}$ content of all batches of this fodder was $27 \cdot 3$ (SE 1.6) $\mu \mathrm{mol} / \mathrm{kg}$. The control animals were maintained on distilled water and the same diet supplemented with zinc chloride to a final concentration of $500 \mu \mathrm{mol} / \mathrm{kg}$ fodder (control fodder). The animals were kept in plastic cages with grids constructed of stainless steel. Precautions were taken to minimize $\mathrm{Zn}$ contamination.

Before the start of the dietary regimen the rats were acclimatized to the semi-synthetic fodder by feeding the $\mathrm{Zn}$-supplemented fodder for $3 \mathrm{~d}$. After this adjustment period the rats were randomly divided into the experimental groups.

$\mathrm{Zn}$ repletion was performed after $\mathrm{Zn}$ depletion by giving the $\mathrm{Zn}$-depleted animals free access to $\mathrm{Zn}$-enriched fodder $(500 \mu \mathrm{mol} \mathrm{Zn} / \mathrm{kg})$. Graded $\mathrm{Zn}$ deficiencies were induced by maintaining the animals on distilled water and $\mathrm{Zn}$-deficient fodder supplemented with $\mathrm{ZnCl}_{2}$ to contents varying between 30 and $100 \mu \mathrm{mol} \mathrm{Zn} / \mathrm{kg}$. Age-matched control rats were maintained on $\mathrm{Zn}$-deficient fodder supplemented with $\mathrm{ZnCl}_{2}$ to a final concentration of $500 \mu \mathrm{mol} \mathrm{Zn} / \mathrm{kg}$.

In one experiment, the 3-week-old animals were pair-fed by maintaining the controls on the same amount of fodder, on a body-weight basis, as that of the rats on $\mathrm{Zn}$-deficient fodder. A third group was given free access to fodder. All three groups received distilled water. Whereas the $\mathrm{Zn}$-depleted group received $\mathrm{Zn}$-free fodder, pair-fed and ad lib.-fed animals were given the same fodder supplemented with $\mathrm{ZnCl}_{2}$ to give a final concentration of $500 \mu \mathrm{mol} \mathrm{Zn} / \mathrm{kg}$ fodder.

\section{Blood samples}

Blood samples were collected from the retrobulbar plexus through capillary tubes. This was done under light ethyl ether anaesthesia. The blood samples were centrifuged at $10600 \mathrm{~g}$ for 2 min and serum was frozen and kept at $-20^{\circ}$ until further analysis. Serum samples for 
$\mathrm{Zn}$ determination were mixed with $0 \cdot 1$ vol. trichloroacetic acid (TCA; 3 mol/l). After centrifugation the supernatant fraction was taken for dilution with redistilled water. Repeated control measurements of the TCA showed no detectable content of $\mathrm{Zn}$ or of $\mathrm{Mg}$.

$\mathrm{Mg}$ and $\mathrm{Zn}$ analyses were performed using atomic absorption spectrophotometry (Perkin-Elmer).

\section{IGF-I radioimmunoassay}

IGF-1 was estimated using IGF-1-antibody UB 286 (raised by L. E. Underwood and J. J. Van Wyk, Pediatric Endocrinology, University of North Carolina, Chapel Hill, NC, USA, donated by National Hormone and Pituitary Program). IGF-1-immunoactivity was measured in diluted rat serum $(1: 400, \mathrm{v} / \mathrm{v})$ after previous extraction in acid-methanol (Flyvbjerg et al. 1989).

For standards and iodination, a full amino acid sequence IGF-1 analogue (AMGEN Biologicals, Thousand Oak, California, USA) was purchased from Amersham International (Amersham, Bucks). All constituents were made up in phosphate buffer (40 mmol/1), pH 8.0, with $2 \mathrm{~g}$ bovine serum albumin (Sigma, St Louis, MO, USA) 1 and sodium merthiolate $(0 \cdot 6 \mathrm{mmol} / 1)$. Separation was achieved using $(6: 1, \mathrm{v} / \mathrm{v}) 200 \mathrm{~g}$, polyethylene glycol 6000 with $5 \mathrm{~g}$ Tween 20 (both from Merck, Darmstadt, Germany/l. Free and antibody-bound activities were counted.

\section{Insulin radioimmunoassay}

Serum insulin was measured by radioimmunoassay as described by Ørskov et al. (1968).

\section{$G H$-releasing factor $(G R F)$ test and $G H$ assay}

Under sodium barbital anaesthesia $(25 \mathrm{mg} / \mathrm{kg}$ body-weight) blood was collected from the retrobulbar plexus after $0,5,10,20$ and $30 \mathrm{~min}$. Independent of body-weight $1 \mu \mathrm{g}$ GRF 40 was injected intravenously in control and $\mathrm{Mg}$ - or $\mathrm{Zn}$-depleted animals after the first baseline blood sample. Rat $\mathrm{GH}(\mathrm{rGH})$ was determined by radioimmunoassay using wickchromatography (Ørskov \& Seyer-Hansen, 1974). rGH and rabbit anti-rGH were donated by National Hormone and Pituitary Program. GRF-40 was obtained from Bachem, Bubendorf, Switzerland.

\section{Statistics}

All results are given as mean values with their standard errors. The significance of difference was assessed by two-tailed $t$ test for groups of non-paired observations, paired $t$ test and by one-way analysis of variance. Linear regression analysis of unweighted values was performed by the method of least squares. Any $P$ value above 0.05 was designated as not significant.

\section{RESULTS}

\section{$M g$ deficiency}

The effects of energy and $\mathrm{Mg}$ intake on body-weight, s-Mg, s-IGF-1 and s-insulin were first analysed in a pair-feeding experiment of $12 \mathrm{~d}$ duration. Table 1 shows that pair-feeding caused a $37 \%$ reduction in weight gain compared with ad lib. feeding while s-Mg was unchanged. In the same experiment the $\mathrm{Mg}$-deficient group showed an additional reduction in weight gain (34\%) while s-Mg had dropped as much as $75 \%$ when compared with the pair-fed controls. In the ad lib.-fed and the pair-fed control groups the same age-dependent increase in s-IGF-1 was observed while in the Mg-deficient group, s-IGF-1 only amounted to $56 \%$ of the value in the pair-fed group after $12 \mathrm{~d}$ on $\mathrm{Mg}$-deficient fodder. In contrast, s-insulin in the Mg-deficient group was not significantly different from that of the pair-fed group. 
Table 1. Effect of magnesium depletion on body-weight, serum $M g$, $(s-M g)$, serum insulinlike growth factor-1 (s-lGF-l) and serum insulin (s-insulin) of rats

(Mean values with their standard errors; no of animals in parentheses)

\begin{tabular}{|c|c|c|c|c|c|c|c|c|}
\hline \multirow[t]{2}{*}{$\begin{array}{c}\text { Group ... } \\
\text { Treatment* ... }\end{array}$} & \multicolumn{2}{|c|}{$\begin{array}{c}1 \\
\text { Ad lib.-fed } \\
\text { controls }(n 7)\end{array}$} & \multicolumn{2}{|c|}{$\begin{array}{c}2 \\
\text { Pair-fed } \\
\text { controls }(n 6)\end{array}$} & \multirow{2}{*}{$\begin{array}{c}\text { Statistical } \\
\text { significance } \\
\text { of difference } \\
\text { l } v .2: \\
P\end{array}$} & \multicolumn{2}{|c|}{$\begin{array}{c}3 \\
\text { Mg-depleted } \\
(n \text { 6) }\end{array}$} & \multirow{2}{*}{$\begin{array}{c}\text { Statistical } \\
\text { significance } \\
\text { of difference } \\
2 \text { v. } 3: \\
P\end{array}$} \\
\hline & Mean & SE & Mean & $\mathrm{SE}$ & & Mean & $\mathrm{SE}$ & \\
\hline \multicolumn{9}{|l|}{ Body-wt (g) } \\
\hline Day 0 & $50 \cdot 2$ & $0 \cdot 8$ & $49 \cdot 7$ & 0.9 & NS & $49 \cdot 7$ & $1 \cdot 2$ & NS \\
\hline Day 12 & $102 \cdot 5$ & $3 \cdot 2$ & $89 \cdot 1$ & $1 \cdot 1$ & $<0.005$ & $75 \cdot 6$ & $2 \cdot 2$ & $<0.001$ \\
\hline \multicolumn{9}{|l|}{$\mathrm{s}-\mathrm{Mg}(\mathrm{mmol} / \mathrm{l})$} \\
\hline Day 0 & $1 \cdot 23$ & 0.03 & $1 \cdot 32$ & 0.03 & NS & $1 \cdot 27$ & 0.03 & NS \\
\hline Day 12 & $1 \cdot 14$ & 0.06 & $1 \cdot 13$ & $0 \cdot 04$ & NS & $0 \cdot 28$ & 0.03 & $<0.001$ \\
\hline \multicolumn{9}{|l|}{$\mathrm{s}-\mathrm{IGF}-1(\mu \mathrm{g} / \mathrm{l})$} \\
\hline Day 0 & 374 & 45 & 295 & 36 & NS & 370 & 33 & NS \\
\hline Day 12 & 817 & 100 & 776 & 75 & NS & 435 & 21 & $<0.001$ \\
\hline \multicolumn{9}{|l|}{ s-insulin $(\mathrm{mU} / \mathrm{l})$} \\
\hline Day 0 & $15 \cdot 0$ & $3 \cdot 6$ & $10 \cdot 7$ & $1 \cdot 5$ & NS & $11 \cdot 4$ & $1 \cdot 1$ & NS \\
\hline Day 12 & $13 \cdot 3$ & $3 \cdot 8$ & $19 \cdot 0$ & $1 \cdot 2$ & NS & $27 \cdot 5$ & 8.9 & NS \\
\hline
\end{tabular}

NS, not significant.

* For details, see pp. 506-507.

The effect of repletion with $\mathrm{Mg}$ after a period of $\mathrm{Mg}$ depletion was evaluated in two experiments. Fig. 1 shows the time-course of changes in body-weight, s-Mg and s-IGF- 1 in a group of rats which were kept on $\mathrm{Mg}$-deficient fodder for 3 weeks and then repleted by changing to the same fodder supplemented with $\mathrm{MgCl}_{2}$ to a content of $50 \mathrm{mmol} / \mathrm{kg}$. The onset of growth retardation was rather slow and a significant reduction in body-weight was not seen until after $7 \mathrm{~d}$. After $17 \mathrm{~d}$ the weight gain ceased. Following repletion, the animals showed an increased relative growth rate compared with the controls but did not catch-up the weight difference which remained almost constant (after 3 weeks of repletion amounting to $37.6 \mathrm{~g}$, compared with a weight difference at the onset of repletion of $41.6 \mathrm{~g}$ ).

In contrast to the slowly-developing growth retardation, the animals on Mg-deficient fodder developed a prompt reduction in $\mathrm{s}-\mathrm{Mg}$. In an additional experiment it was observed that s-Mg of the animals on Mg-deficient fodder after $1 \mathrm{~d}$ amounted to $66 \%$ of that of the animals on control fodder $(0.76$ (SE 0.06$) \mathrm{mmol} / 1(n 8) \vee 1.16$ (SE 0.03$) \mathrm{mmol} / 1(n 8), P<$ 0.001 , unpaired $t$ test). After $2 \mathrm{~d}$ this percentage had dropped to $43(0.47$ (SE 0.04) $\mathrm{mmol} / 1$ $v 1.09$ (SE 0.04) mmol/l, $P<0.001$, unpaired $t$ test). Fig. $1(b)$ shows that after $\mathrm{Mg}$ repletion $\mathrm{s}-\mathrm{Mg}$ was completely restored within the first week. In another experiment animals which had been fed on a Mg-deficient diet for $14 \mathrm{~d}$ and then repleted for 1 and $2 \mathrm{~d}$ were evaluated. After $14 \mathrm{~d}$ of $\mathrm{Mg}$ depletion $\mathrm{s}-\mathrm{Mg}$ was reduced to $20 \%$ of control level $(0.22$ $(\mathrm{SE} 0.03) \mathrm{mmol} / 1(n 5) \vee 1.10(\mathrm{SE} 0.03) \mathrm{mmol} / \mathrm{l}(n 7), P<0.001)$. After 1 and $2 \mathrm{~d}$ of $\mathrm{Mg}$ repletion $\mathrm{s}-\mathrm{Mg}$ had risen to 75 and $90 \%$ of the control level respectively (day $15 \quad 0.87$ (SE 0.05$) \mathrm{mmol} / 1$ v 1.16 (SE 0.03$) \mathrm{mmol} / 1, \quad P<0.001$, unpaired $t$ test; day 160.91 (SE 0.05$) \mathrm{mmol} / \mathrm{l} v 1.01$ (SE 0.02$) \mathrm{mmol} / \mathrm{l}$, not significant, unpaired $t$ test). This confirms that $\mathrm{s}-\mathrm{Mg}$ levels show a rapid response to changes in dietary $\mathrm{Mg}$ supplies.

In the control animals s-IGF-1 showed the characteristic age-dependent increase during the course of the experiment, while in the $\mathrm{Mg}$-deficient group this increase was almost abolished (Fig. 1(c)). After 3 weeks on Mg-deficient fodder s-IGF-1 was only $40 \%$ of the value in the control group. After 1 week of $\mathrm{Mg}$ repletion there seemed to be a tendency 

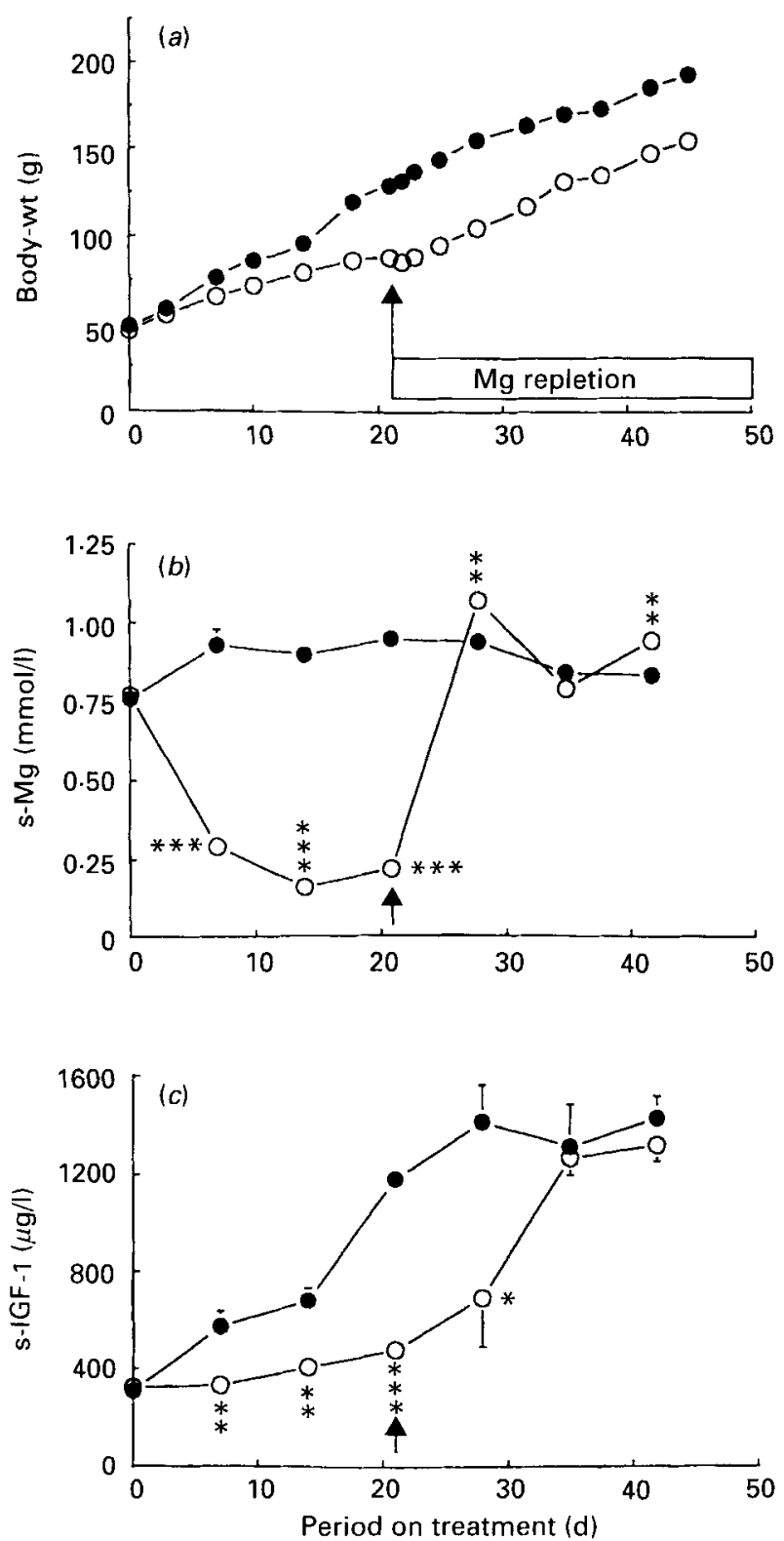

Fig. 1. Effect of magnesium depletion and $\mathrm{Mg}$ repletion on $(a)$ body-weight, $(b)$ serum $\mathrm{Mg}(\mathrm{S}-\mathrm{Mg})$ and $(c)$ serum insulin-like growth factor-1 (s-IGF-1). Groups of 3-week-old rats were maintained on Mg-deficient fodder $(1.6 \mathrm{mmol} / \mathrm{kg})(\mathrm{O}-\mathrm{O})$ or on the same fodder supplemented with magnesium chloride to a content of $50 \mathrm{mmol} / \mathrm{kg}$ ( ) After $21 \mathrm{~d}$ the rats on $\mathrm{Mg}$-deficient fodder were $\mathrm{Mg}$ repleted by changing to the $\mathrm{Mg}$ supplemented fodder (for details of composition, see p. 506). Each point is the mean of five Mg-depleted-repleted and six control animals with their standard errors represented by vertical bars where this exceeds the size of the symbols. The difference between the body-weight of the controls and that of the $\mathrm{Mg}$-depleted-repleted rats was significant $(P<0 \cdot 01)$ at all points except on days 0 and 3. Mean values for s-Mg or s-IGF-l of the controls were significantly different from those of the Mg-depleted-repleted rats: ${ }^{*} P<0.05,{ }^{* *} P<0.01,{ }^{* * *} P<0.001$. 
Table 2. Effect of magnesium depletion and subsequent repletion on growth variables, serum $\mathrm{Mg}(s-M g)$ and serum insulin-like growth factor-1 $(s-I G F-1)$ in rats

(Mean values with their standard errors; no. of animals in parentheses)

\begin{tabular}{|c|c|c|c|c|c|c|c|c|}
\hline \multirow[t]{2}{*}{$\begin{array}{c}\text { Group ... } \\
\text { Treatment* }\end{array}$} & \multicolumn{2}{|c|}{$\begin{array}{l}1 \\
\text { Repleted by } \\
\text { relative PF } \\
\left(\begin{array}{l}n 7 \\
(n)\end{array}\right.\end{array}$} & \multicolumn{2}{|c|}{$\begin{array}{c}2 \\
\text { Repleted by } \\
\text { absolute PF } \\
(n 8)\end{array}$} & \multicolumn{2}{|c|}{$\begin{array}{c}3 \\
\text { Mg-depleted } \\
\text { for } 24 \mathrm{~d} \\
(n 8)\end{array}$} & \multicolumn{2}{|c|}{$\begin{array}{l}\text { Statistical significance } \\
\text { of difference }(P) \text { for: }\end{array}$} \\
\hline & Mean & $\mathrm{SE}$ & Mean & $\mathrm{SE}$ & Mean & $\mathrm{SE}$ & 1 v. 3 & 2 v. 3 \\
\hline \multicolumn{9}{|l|}{ Body-wt (g) } \\
\hline Day 0 & $52 \cdot 8$ & $0 \cdot 2$ & $53 \cdot 8$ & $1 \cdot 6$ & $54 \cdot 4$ & $1 \cdot 6$ & NS & NS \\
\hline Day 17 & $92 \cdot 4$ & $4 \cdot 2$ & $92 \cdot 3$ & 1.9 & $90 \cdot 0$ & $2 \cdot 4$ & NS & NS \\
\hline Day 24 & $111 \cdot 4$ & $3 \cdot 3$ & $107 \cdot 2$ & $1 \cdot 8$ & $96 \cdot 6$ & $2 \cdot 7$ & $<0.005$ & $<0.005$ \\
\hline \multicolumn{9}{|l|}{ Soleus wt (mg) } \\
\hline Day 24 & $48 \cdot 4$ & $1 \cdot 7$ & $47 \cdot 2$ & $1 \cdot 5$ & $39 \cdot 0$ & $2 \cdot 2$ & $<0.01$ & $<0.01$ \\
\hline \multicolumn{9}{|l|}{ EDL wt (mg) } \\
\hline Day 24 & $41 \cdot 6$ & $1 \cdot 8$ & $40 \cdot 7$ & $1 \cdot 7$ & $27 \cdot 5$ & $1 \cdot 8$ & $<0.001$ & $<0.001$ \\
\hline Tibia length $(\mathrm{mm})$ & & & & & & & & \\
\hline Day 24 & $30 \cdot 9$ & $0 \cdot 4$ & $30 \cdot 5$ & $0 \cdot 3$ & $29 \cdot 5$ & $0 \cdot 3$ & $<0.02$ & $<0-025$ \\
\hline \multicolumn{9}{|l|}{$\mathrm{s}-\mathrm{Mg}(\mathrm{mmol} / \mathrm{l})$} \\
\hline Day 0 & 1.09 & 005 & 1.07 & 0.05 & $1 \cdot 02$ & 0.08 & NS & NS \\
\hline Day 17 & $0 \cdot 14$ & 0.02 & $0 \cdot 17$ & 0.02 & 0.17 & $0 \cdot 01$ & NS & NS \\
\hline Day 24 & 1.08 & 0.02 & $1 \cdot 13$ & 0.03 & 0.23 & 0.01 & $<0.001$ & $<0.001$ \\
\hline \multicolumn{9}{|l|}{$\mathrm{s}-\mathrm{IGF}-1(\mu \mathrm{g} / 1)$} \\
\hline Day 0 & 219 & 25 & 235 & 19 & 252 & 33 & NS & NS \\
\hline Day 17 & 414 & 49 & 375 & 38 & 370 & 48 & NS & NS \\
\hline Day 24 & 504 & 26 & 454 & 28 & 333 & 40 & $<0.005$ & $<0.03$ \\
\hline
\end{tabular}

PF, pair-feeding; NS, not significant; EDL, extensor digitorum longus.

* For details, see pp. 506-507.

towards a rise in s-IGF-1 (not significant), and after 2 weeks of $\mathrm{Mg}$ repletion a complete normalization of s-IGF-1 was seen.

Since the amount of fodder consumed in ad lib.-fed animals increases with body-weight, a restriction in food supply of the control group to the absolute amount of fodder consumed in the Mg-depleted group would, after a few days, lead to semi-starvation. As a consequence, we chose in the first pair-feeding experiment to give the pair-fed animals the same amount, on a body-weight basis, as that consumed by the $\mathrm{Mg}$-deficient group (see Table 1). Table 2 shows the results from another experiment where repletion with $\mathrm{Mg}$, after a $\mathrm{Mg}$ depletion of $17 \mathrm{~d}$ duration, was evaluated by means of relative and absolute pairfeeding.

After $7 \mathrm{~d}$ of $\mathrm{Mg}$-repletion both group 1 (relative pair-fed) and group 2 (absolute pair-fed) showed normalization of s- $\mathrm{Mg}$ and a significant increase in all growth variables, i.e. bodyweight, soleus and extensor digitorum longus (EDL) muscle weight as well as length of tibia. The two groups that were repleted did not differ from each other with respect to these growth variables. Body-weight was significantly correlated to wet weight of soleus $(r 0.74$, $P<0.001)$, wet weight of EDL $(r 0.85, P<0.001)$ and to length of tibia $(r 0.80, P<0.001)$. Table 2 shows s-IGF-1 which increased significantly in both repleted groups but decreased in the group which was not repleted. Although there was a tendency towards a more pronounced increase in group 1 , there was no significant difference between group 1 and group 2.

In order to determine by how much dietary $\mathrm{Mg}$ can be reduced before growth is 
(a)
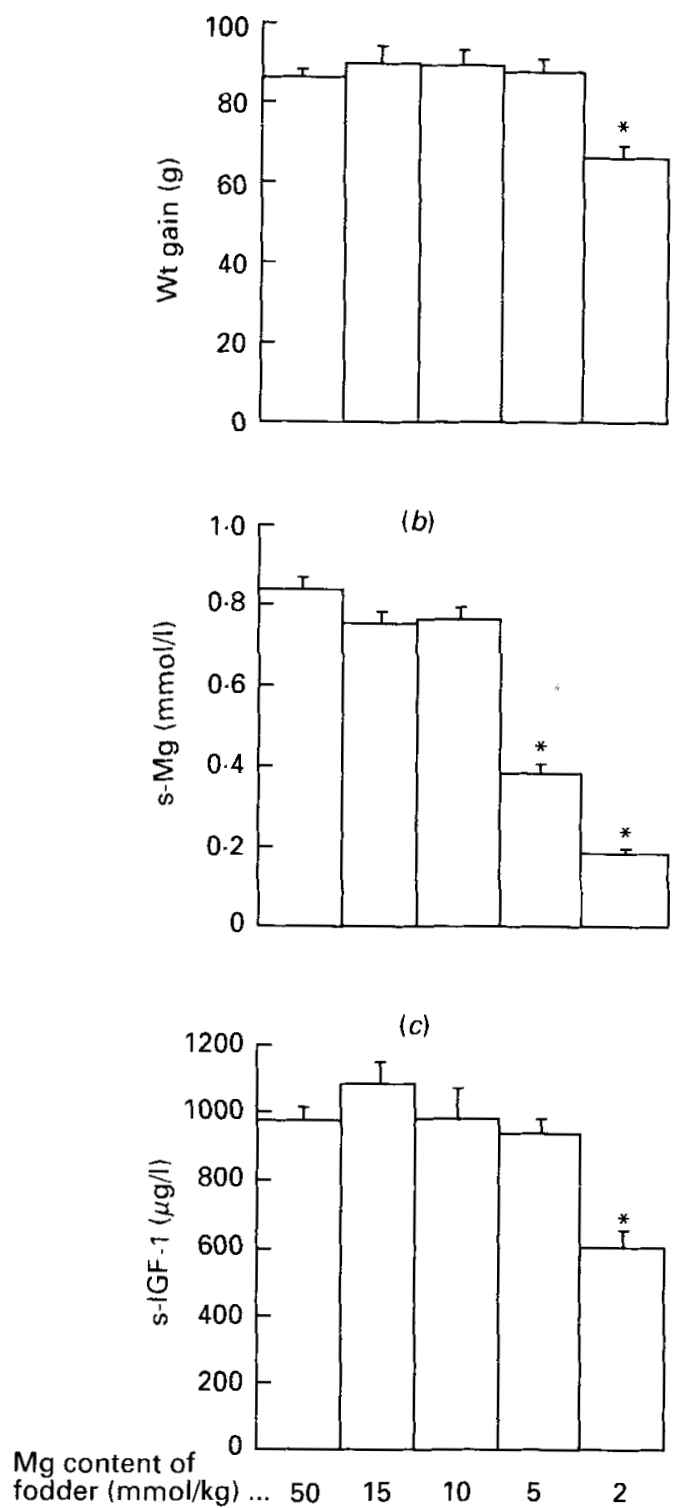

Fig. 2. Effect of graded magnesium-deficient fodder on weight gain (a), serum $\mathrm{Mg}(\mathrm{s}-\mathrm{Mg})(b)$ and serum insulinlike growth factor-1 (s-1GF-1) (c). Rats (3.5 weeks old) were maintained for $21 \mathrm{~d}$ on $\mathrm{Mg}$-deficient fodder which had been supplemented by graded amounts of magnesium chloride to a final content of $2-50 \mathrm{mmol} / \mathrm{kg}$ (for details of composition, see p. 506). Values are means with their standard errors represented by vertical bars for six to tweive animals. Mean values for $\mathrm{Mg}$-deficient animals were significantly different from those for controls (kept on fodder containing $50 \mathrm{mmol} \mathrm{Mg} / \mathrm{kg}$ ): ${ }^{*} P<0 \cdot 001$.

impaired, a dose-effect study was performed. As shown in Fig. 2, the dietary supplement of $\mathrm{Mg}$ had to be reduced to the lowest content $(2 \mathrm{mmol} / \mathrm{kg})$ before a significant growth retardation could be observed. In accordance with this, s-IGF-1 showed a significant reduction at this dietary $\mathrm{Mg}$ content. In contrast, $\mathrm{s}-\mathrm{Mg}$ dropped to $44 \%$ of the control level already at a dietary $\mathrm{Mg}$ content of $5 \mathrm{mmol} / \mathrm{kg}$. 


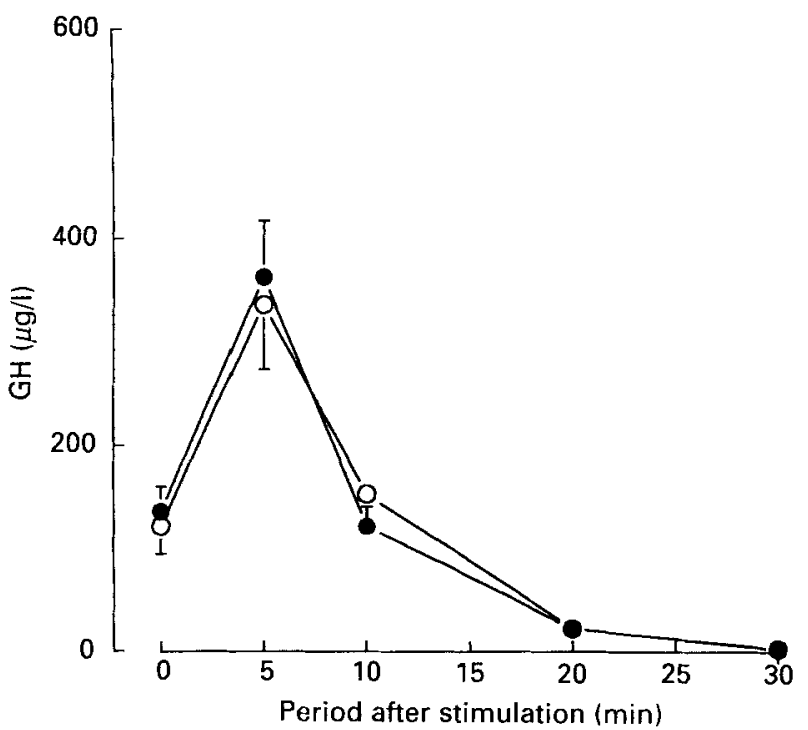

Fig. 3. Effect of intravenous stimulation with growth hormone (GH)-releasing factor (GRF) on serum GH (s$\mathrm{GH})$ in magnesium-depleted $(\mathrm{O}-\mathrm{O})$ and control $(-\infty)$ rats. Groups of 3-week-old rats were maintained on $\mathrm{Mg}$-deficient fodder or the same fodder enriched with $\mathrm{Mg}$ to a final content of $50 \mathrm{mmol} \mathrm{Mg} / \mathrm{kg}$ (for details of composition, see p. 506). After $14 \mathrm{~d}$ the animals were given an intravenous injection of $1 \mu \mathrm{g} G \mathrm{RF}$ and blood samples were collected from the retrobulbar plexus at the indicated intervals of time (for details of procedures, see pp. 507-508). Values are means with their standard errors represented by vertical bars for eight $\mathrm{Mg}$-depleted and nine control animals. The differences between controls and $\mathrm{Mg}$-depleted animals were not statistically significant.

Fig. 3 shows s-GH levels during a GRF test of ad lib.-fed and Mg-depleted rats. The GRF test showed a mean GH peak level after $5 \mathrm{~min}$ of 363 (SE 54) $\mu \mathrm{g} / 1$ in control animals whereas in $\mathrm{Mg}$-depleted animals the GH peak amounted to 336 (SE 63) $\mu \mathrm{g} / 1$ (not significant). The rather high GH level observed at zero time in the present experiment may be explained by the fact that pentobarbital anaesthesia in rats induces an increase in $\mathrm{GH}$ levels lasting more than 90 min (Takahashi et al. 1971). It should be noted that basal (unstimulated) serum GH was the same in the two groups. Over the observation period of $14 \mathrm{~d}$, animals on Mg-deficient fodder showed a weight gain of 40.2 (SE 1.7) g v62.6 (SE 2.4) $\mathrm{g}$ in control animals $(P<0.001)$. After $14 \mathrm{~d}$ on $\mathrm{Mg}$-deficient fodder s-IGF amounted to 515 (SE 66) $\mu \mathrm{g} / \mathrm{l}$, while in the control group s-IGF-1 showed a value of 736 (SE 48) $\mu \mathrm{g} / \mathrm{l}(P<0.02)$.

\section{Zn deficiency}

The effects of energy and $\mathrm{Zn}$ intake on body-weight, s-Zn, s-IGF-1 and s-insulin were evaluated in a pair-feeding experiment. As shown in Table 3, the $\mathrm{Zn}$-deficient animals had a weight gain amounting to only $17 \%$ of that seen in the pair-fed control animals, while the weight gain in the pair-fed and ad lib.-fed controls did not differ. After $14 \mathrm{~d}$ of $\mathrm{Zn}$ depletion s-Zn was reduced by $80 \%$ compared with the pair-fed group, whereas $\mathrm{s}-\mathrm{Zn}$ in the two control groups did not differ from each other. The normal age-dependent increase in $\mathrm{s}-\mathrm{IGF}-1$ was seen in both the pair-fed and the ad lib.-fed control groups, while in the $\mathrm{Zn}$ deficient group s-IGF-1 showed a small decrease. In all groups s-insulin showed great variability, but was significantly reduced in the $\mathrm{Zn}$-deficient group compared with the control groups.

Fig. 4 shows the results of an experiment where 3-week-old animals were $\mathrm{Zn}$-depleted or 
Table 3. Effect of zinc depletion on body-weight, serum $\mathrm{Zn}(s-\mathrm{Zn})$, serum insulin-like growth factor-l (s-IGF-l) and serum insulin (s-insulin) in rats

(Mean values with their standard errors; no. of animals in parentheses)

\begin{tabular}{|c|c|c|c|c|c|c|c|c|}
\hline \multirow[t]{2}{*}{$\begin{array}{c}\text { Group ... } \\
\text { Treatment* ... }\end{array}$} & \multicolumn{2}{|c|}{$\begin{array}{c}1 \\
\text { Ad lib.-fed } \\
\text { controls }(n 6)\end{array}$} & \multicolumn{2}{|c|}{$\begin{array}{c}2 \\
\text { Pair-fed } \\
\text { controls }(n 6)\end{array}$} & \multirow{2}{*}{$\begin{array}{c}\text { Statistical } \\
\text { significance } \\
\text { of difference } \\
1 \text { v. } 2: \\
P\end{array}$} & \multicolumn{2}{|c|}{$\begin{array}{c}3 \\
\text { Zn-depleted } \\
(n 5)\end{array}$} & \multirow{2}{*}{$\begin{array}{c}\text { Statistical } \\
\text { significance } \\
\text { of difference } \\
2 v .3: \\
P\end{array}$} \\
\hline & Mean & $\mathrm{SE}$ & Mean & SE & & Mean & SE & \\
\hline \multicolumn{9}{|l|}{ Body-wt (g) } \\
\hline Day 0 & $48 \cdot 5$ & 10 & $48 \cdot 7$ & $1 \cdot 2$ & NS & $48 \cdot 1$ & $1 \cdot 1$ & NS \\
\hline Day 14 & $114 \cdot 1$ & $3 \cdot 3$ & $109 \cdot 5$ & $4 \cdot 3$ & NS & $58 \cdot 7$ & $1 \cdot 8$ & $<0.001$ \\
\hline \multicolumn{9}{|l|}{$\mathrm{s}-\mathrm{Zn}(\mu \mathrm{mol} / \mathrm{l})$} \\
\hline Day 0 & $22 \cdot 3$ & 1.9 & $23 \cdot 2$ & $1 \cdot 7$ & NS & $23 \cdot 4$ & $1 \cdot 4$ & NS \\
\hline Day 14 & $25 \cdot 3$ & 0.7 & $23 \cdot 6$ & $0 \cdot 8$ & NS & $4 \cdot 8$ & $1 \cdot 1$ & $<0.001$ \\
\hline \multicolumn{9}{|l|}{ s-IGF-1 $(\mu \mathrm{g} / 1)$} \\
\hline Day 0 & 321 & 50 & 429 & 37 & NS & 416 & 23 & NS \\
\hline Day 7 & 598 & 63 & 561 & 42 & NS & 267 & 36 & $<0.005$ \\
\hline Day 14 & 1062 & 61 & 953 & 53 & NS & 293 & 24 & $<0.001$ \\
\hline \multicolumn{9}{|c|}{ s-insulin $(\mathrm{mU} / \mathrm{l})$} \\
\hline Day 0 & $18 \cdot 0$ & 5.9 & $11 \cdot 8$ & 1.9 & NS & $21 \cdot 2$ & $2 \cdot 4$ & NS \\
\hline Day 14 & $24 \cdot 5$ & $5 \cdot 6$ & $28 \cdot 0$ & $4 \cdot 4$ & NS & $9 \cdot 6$ & $1 \cdot 7$ & $<0.01$ \\
\hline
\end{tabular}

maintained on the same fodder but supplemented with $\mathrm{Zn}$. The growth retardation in the $\mathrm{Zn}$-deficient group was earlier and more pronounced than that seen during $\mathrm{Mg}$ deficiency (Fig 4(a)), Following $7 \mathrm{~d}$ on $\mathrm{Zn}$-deficient fodder the body-weight was significantly reduced and after $17 \mathrm{~d}$, weight gain amounted to only $26 \%$ of that of the controls. After $17 \mathrm{~d}$ the $\mathrm{Zn}$-deficient animals were switched to the $\mathrm{Zn}$-supplemented fodder and then showed an immediate increase in body-weight and in growth rate. During the following weeks, however, the growth rate declined and the Zn-depleted-repleted animals did not reach the same body-weight as the controls. After $42 \mathrm{~d}$ of $\mathrm{Zn}$ repletion the weight difference between the $\mathrm{Zn}$-depleted-repleted and the controls amounted to $32 \mathrm{~g}$ (results not shown).

$\mathrm{S}-\mathrm{Zn}$ (Fig. 4(b)) showed a rapid and pronounced decrease during the course of the $\mathrm{Zn}$ depletion. After $7 \mathrm{~d} \mathrm{~s}-\mathrm{Zn}$ amounted to only $34 \%$ of the level in the control animals. In another experiment where rats had been fed on the $\mathrm{Zn}$-deficient diet for $3 \mathrm{~d}$, s-Zn was reduced to $42 \%$ of the level measured in the control animals ( $\mathrm{Zn}$-deficient 7.7 (SE 0.5$) \mu \mathrm{mol} / 1(n 7)$, controls $18.0($ SE 1.2$) \mu \mathrm{mol} / 1(n 7)(P<0.001))$. When Zn-depleted animals were repleted they showed a rapid increase and s- $\mathrm{Zn}$ became normalized within $3 \mathrm{~d}$.

Fig. 4(c) shows that in the control animals s-IGF-1 increased in the age-dependent fashion, while in the $\mathrm{Zn}$-deficient animals a decrease was seen. After $\mathrm{Zn}$ repletion, however, there was a significant increase in s-IGF- 1 already after $3 \mathrm{~d}(P<0.05)$, but s-IGF-1 was not normalized until after $17 \mathrm{~d}$ of repletion.

In order to examine dose effect relationships, 3-week-old rats were maintained for $12 \mathrm{~d}$ on $\mathrm{Zn}$-deficient fodder which had been supplemented by graded amounts of $\mathrm{ZnCl}_{2}$ to a content between 30 and $500 \mu \mathrm{mol} \mathrm{Zn/kg}$. As shown in Fig. 5(a), a significant inhibition of growth was seen at a $\mathrm{Zn}$ content of $75 \mu \mathrm{mol} / \mathrm{kg}$. No further inhibition was produced by reducing the $\mathrm{Zn}$ content to 50 or $30 \mu \mathrm{mol} / \mathrm{kg}$. The intake of fodder containing $100 \mu \mathrm{mol}$ $\mathrm{Zn} / \mathrm{kg}$ caused a significant reduction in $\mathrm{s}-\mathrm{Zn}$, and fodder containing lower amounts of $\mathrm{Zn}$ caused more pronounced reductions in $\mathrm{s}-\mathrm{Zn}$. The decrease in s-IGF-1 corresponded very 

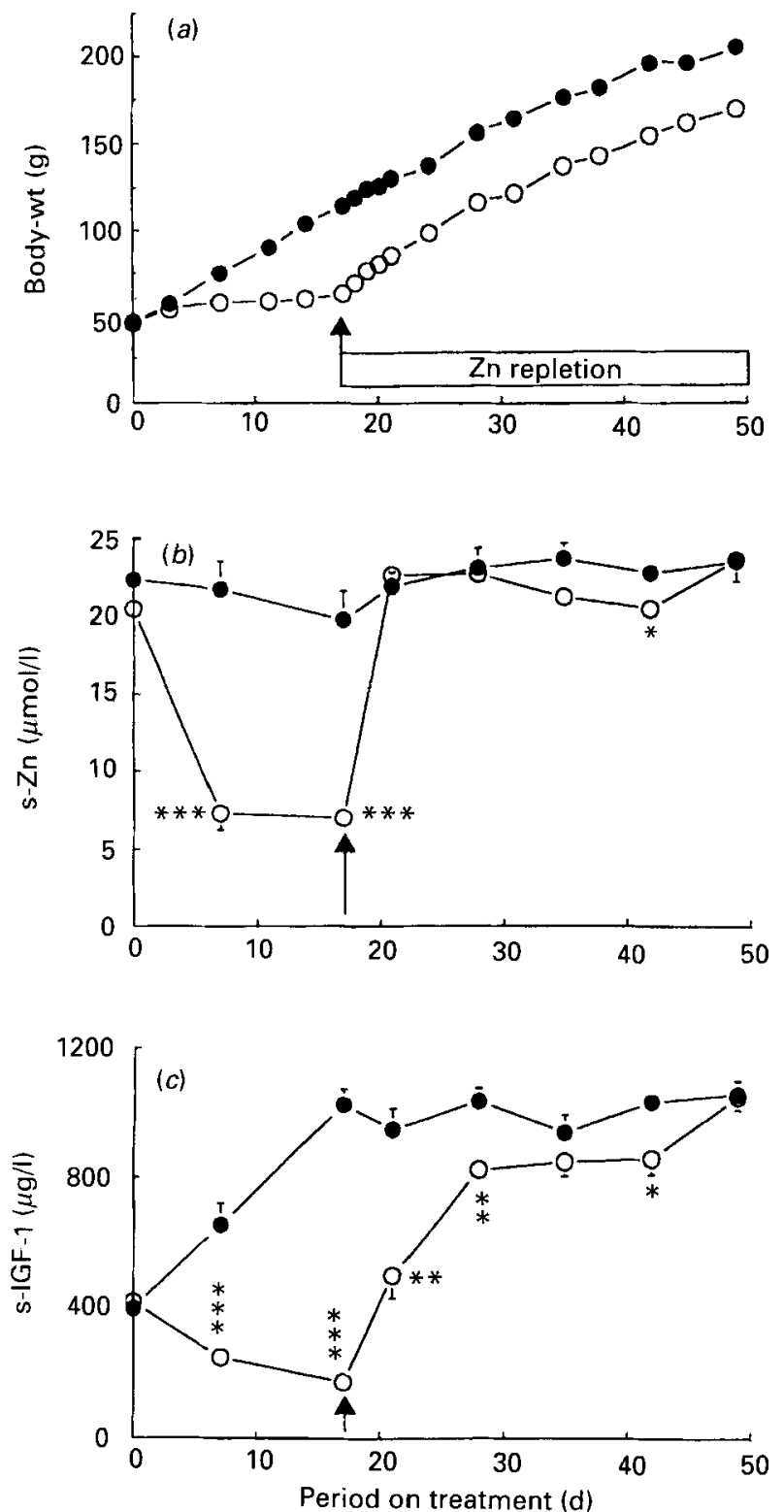

Fig. 4. Effect of zinc depletion and $\mathrm{Zn}$ repletion on $(a)$ body-weight, $(b)$ serum $\mathrm{Zn}(\mathrm{s}-\mathrm{Zn})$ and $(c)$ serum insulinlike growth factor-1 (s-IGF-1). Groups of 3-week-old rats were maintained on $\mathrm{Zn}$-deficient fodder $(27 \mu \mathrm{mol} / \mathrm{kg})$ $(\mathrm{O}-\mathrm{O})$ or on the same fodder supplemented with zinc chloride to a content of $500 \mu \mathrm{mol} / \mathrm{kg}$ (O-C) (for details of composition, see p. 506). After $17 \mathrm{~d}$ the rats on $\mathrm{Zn}$-deficient fodder were Zn-repleted by changing to the $\mathrm{Zn}$-supplemented fodder. Points are means with their standard errors represented by vertical bars for five $\mathrm{Zn}$ depleted/repleted or six control animals, where this exceeds the size of the symbols. Mean values for body-weights of the $\mathrm{Zn}$-depleted-repleted rats were significantly different from those of the controls $(P<0.002$ or less $)$ at all points except on days 0 and 3. Mean values for s- $\mathrm{Zn}$ or s-IGF-1, of the $\mathrm{Zn}$-depleted-repleted rats were significantly different from those of the control rats: ${ }^{*} P<0 \cdot 05,{ }^{* *} P<0.005,{ }^{* * *} P<0.001$. 

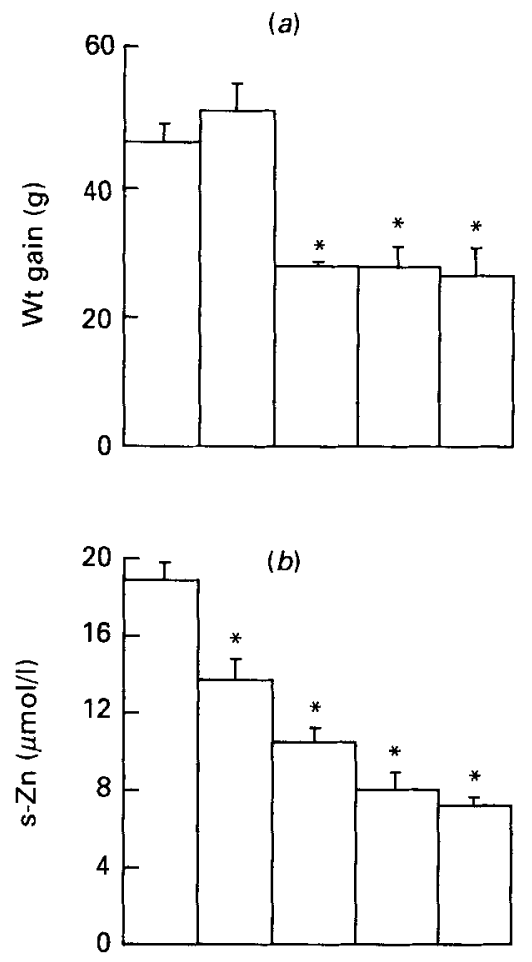

\section{Zn content of}

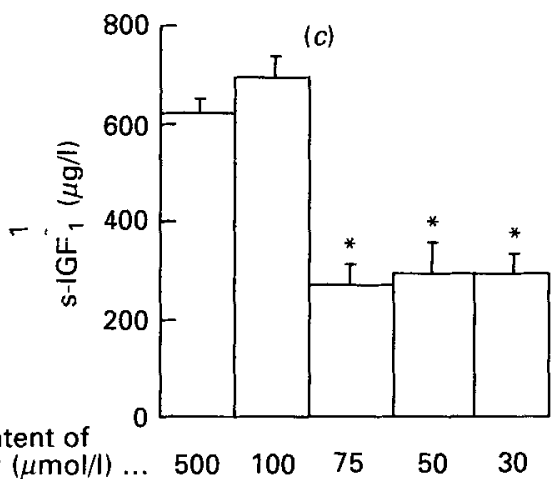

Fig. 5. Effect of graded zinc-deficient fodder on weight gain $(a)$, serum $\mathrm{Zn}(\mathrm{s}-\mathrm{Zn})(b)$ and serum insulin-like growth factor-1 (s-IGF-1) (c). Rats (3 weeks old) were maintained for $12 \mathrm{~d}$ on $\mathrm{Zn}$-deficient fodder which had been supplemented by graded amounts of zinc chloride to a final content of $30-500 \mu \mathrm{mol} / \mathrm{kg}$ (for details of composition, see p. 506). Values are means with their standard errors represented by vertical bars for six to twelve animals. Mean values for $\mathrm{Zn}$-deficient animals were significantly different from those for controls (kept on fodder containing $500 \mu \mathrm{mol} \mathrm{Zn} / \mathrm{kg}): * P<0.001$.

well with the reduction in weight gain, the values for s-IGF-1 being significantly decreased for dietary intakes of 75,50 and $30 \mu \mathrm{mol} / \mathrm{kg}$.

Fig. 6 shows serum GH levels during a GRF test of ad lib.-fed and Zn-depleted rats. The GRF-test showed a mean GH peak level of 774 (SE 61) $\mu \mathrm{g} / \mathrm{l}$ in control animals, whereas in Zn-depleted animals the GH peak amounted to 657 (SE 90) $\mu \mathrm{g} / \mathrm{l}$ (not significant). Over the observation period of $12 \mathrm{~d}$, animals on $\mathrm{Zn}$-deficient fodder showed a weight gain of 47.2 


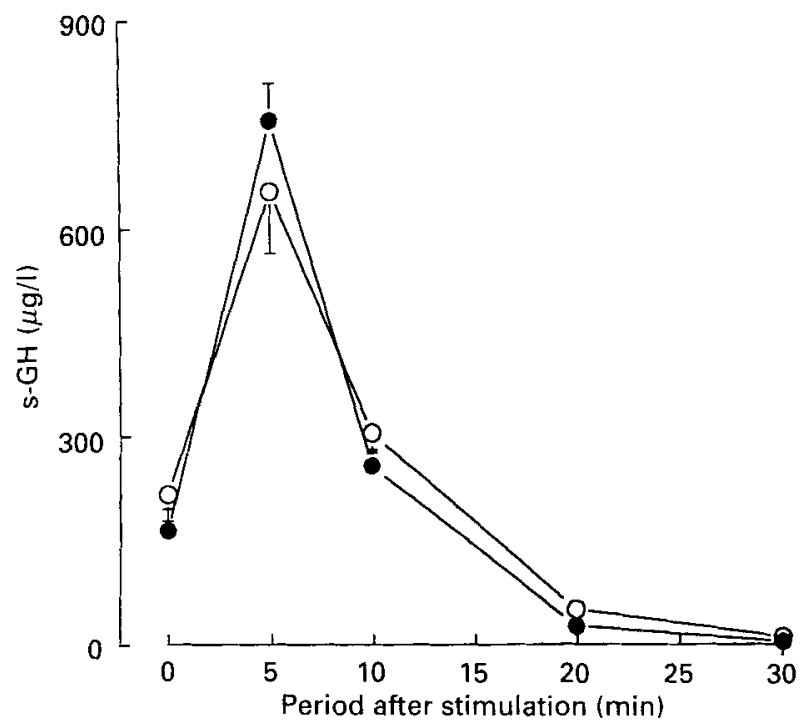

Fig. 6. Effect of intravenous stimulation with growth hormone (GH)-releasing factor (GRF) on serum GH (s-GH) in depleted $(\mathrm{O}-\mathrm{O})$ and control ( - $)$ rats. Groups of 4-week-old rats were maintain on $\mathrm{Zn}$-deficient fodder or the same fodder enriched with $\mathrm{Zn}$ to a final content of $500 \mu \mathrm{mol} \mathrm{Zn/kg}$ (for details of composition, see p. 506). After $12 \mathrm{~d}$ the animais were given an intravenous injection of $1 \mu \mathrm{g}$ GRF and blood samples were collected from the retrobulbar plexus at the indicated intervals of time (for details of procedures, see pp. 507-508). Values are means with their standard errors represented by vertical bars for seven $\mathrm{Zn}$-depleted and seven control animals. The differences between controls and $\mathrm{Zn}$-depleted animals were not statistically significant.

(SE 2.6) $\mathrm{g} v 59 \cdot 2$ (SE 2.4) $\mathrm{g}$ in control animals $(P=0 \cdot 005)$. At the start of the experiment, the animals in the control group showed a s-IGF-1 value of 884 (SE 107) $\mu \mathrm{g} / 1$, while the group which was given $\mathrm{Zn}$-deficient fodder showed a value of 914 (SE 92) $\mu \mathrm{g} / \mathrm{l}$ (not significant). After $12 \mathrm{~d}$ on $\mathrm{Zn}$-deficient fodder s-IGF-1 had decreased to 848 (SE 60) $\mu \mathrm{g} / 1$, while in the control group the s-IGF-1 concentration had increased to 1094 (SE 51$) \mu \mathrm{g} / \mathrm{I}(P<0 \cdot 01)$. After $12 \mathrm{~d}$ on $\mathrm{Zn}$-deficient fodder $\mathrm{s}-\mathrm{Zn}$ amounted to 6.4 (SE 1.0) $\mu \mathrm{mol} / 1$ whereas in the control group s-Zn was 14.2 (SE 0.7$) \mu \mathrm{mol} / 1(P<0.001)$. The animals in this GRF test were older than the animals used in the GRF test after Mg depletion (Fig. 3). This is reflected in the higher s-IGF-1 values in the experiment with the $\mathrm{Zn}$-deficient animals.

\section{DISCUSSION}

The present study was undertaken with the purpose of evaluating the serum levels of $\mathrm{Mg}$, $\mathrm{Zn}, \mathrm{IGF}-1$, insulin and $\mathrm{GH}$ during dietary $\mathrm{Mg}$ and $\mathrm{Zn}$ deficiency and to compare these variables with changes in growth.

\section{Growth retardation}

As in earlier studies, insufficient supplies of $\mathrm{Mg}$ or $\mathrm{Zn}$ both resulted in retarded growth rates, but growth inhibition during $\mathrm{Mg}$ deficiency was slower in onset and less pronounced than that seen during $\mathrm{Zn}$ deficiency.

Whereas in young rats general malnutrition retards cell multiplication resulting in a permanent stunting of body mass, the predominant effect of malnutrition during early adulthood is a reduced cell size allowing compensatory growth after refeeding (Winick \& Noble, 1966; Pitts, 1986). This is in good agreement with the incomplete compensatory growth of the young animals in our repletion experiments. 
Since inadequate supplies of $\mathrm{Mg}$ and, in particular, $\mathrm{Zn}$ may reduce the food intake, it is important to perform valid pair-feeding experiments. Frequently, pair-feeding studies have been performed by offering the pair-fed animals the same absolute amount of fodder as that consumed by the deficient group on the previous day (absolute pair-feeding) (George \& Heaton, 1978; O'Leary et al. 1979; Giugliano \& Millward 1984; Southon et al. 1985). It is our experience that in young animals this treatment leads to severe discomfort and even death in the pair-fed control group. Furthermore, since the daily consumption of fodder increases considerably in this age-group, a prolonged pair-feeding experiment, performed as absolute pair-feeding, would lead to relative starvation as the pair-fed animals grow faster than the deficient animals. So it is obvious that if one examines growth and endocrine variables after absolute pair-feeding, the difference between animals fed on a deficient diet and animals fed on a control diet but semi-starved will be demonstrated. This tends to underestimate the effect of $\mathrm{Mg}$ or $\mathrm{Zn}$ deficiency per se. Therefore, we had to refrain from such experiments and analyse the effects of absolute pair-feeding in the relatively shorter repletion experiment only.

The problem is illustrated by the study of Giugliano \& Millward (1984) where relative food intake given as $\mathrm{g} / \mathrm{g}$ body-weight $\mathrm{t}^{0.75}$ was 0.38 in the ad lib.-fed control animals. In the $\mathrm{Zn}$-deficient group a decrease from 0.28 to 0.20 was seen within 2 weeks, whereas in the pair-fed group a value as low as 0.17 was reached. In the study of Bolze et al. (1987) the consequence of absolute pair-feeding was that $\mathrm{Zn}$-deficient animals had a food intake of $178 \mathrm{~kJ}(42.6 \mathrm{kcal}) / \mathrm{g}$ body-weight, while their pair-fed mates received only $143 \mathrm{~kJ}$ (34.2 kcal)/g body-weight. This difficulty of separating effects of reduced food intake from $\mathrm{Zn}$ deficiency per se was also emphasized by the study of O'Leary et al. (1979) who concluded that conventional pair-feeding may be insufficient to allow such distinctions to be made.

To prevent the semi-starvation of the pair-fed animals in a depletion experiment, we instead chose to feed them the same relative amount of fodder, i.e. the same amount, as a percentage of body weight, as that consumed in the group which received restricted $\mathrm{Mg}$ or $\mathrm{Zn}$ supplies, (relative pair-feeding). This would make the pair-fed and the deficient animals comparable in relation to energy supply, and the only variable would be the supply of the relevant mineral.

It should be noted that the growth inhibition of the deficient animals compared with the pair-fed animals in the present study was much larger than in earlier studies (O'Leary et al. 1979; Giugliano \& Millward, 1984). So the results of the present study confirm that both $\mathrm{Mg}$ deficiency and $\mathrm{Zn}$ deficiency per se have a restrictive effect on growth independent of the reduction in food intake and, more importantly, that this effect may be even larger than earlier suggested.

\section{Serum concentrations of $\mathrm{Mg}$ and $\mathrm{Zn}$}

As in earlier studies (Hunt, 1971; Wilkins et al. 1972), it was found that s-Mg and s-Zn underwent a pronounced decline in response to reduced dietary supplies and were promptly normalized after repletion. This is in contrast with the rather small or undetectable reduction of the elements in skeletal muscle (Miller, 1969; Hunt, 1971; O'Leary et al. 1979), and suggests that the serum changes might be of importance as a mediator for regulating s-IGF-1.

\section{Serum levels of IGF-1, GH and insulin}

The major new observation is that $\mathrm{Mg}$ deficiency is accompanied by a pronounced reduction in s-IGF- 1 and that this reduction is reversible during repletion. These alterations in s-IGF-1 factors suggest an explanation for the retarded growth seen during $\mathrm{Mg}$ deficiency.

It has been recognized for several years that the dietary supplies of energy and protein 
are important determinants of concentration s-IGF-1 and that s-IGF-1 might be used as a sensitive index of nutritional status. Restriction of protein or energy both lead to reduced s-IGF-1 (Isley et al. 1983; Fliesen et al. 1989). On this background it is essential to design experiments that allow a distinction between variations in s-IGF-1 that can be accounted for by fasting and those that can be accounted for by a specific nutritional deficiency.

The reduction in s-IGF-1 was seen in comparison with relative pair-fed controls, an experimental set-up where the rats receive comparable amounts of energy without being semi-starved. Since this is the first report on s-IGF-1 during Mg deficiency, we wanted in addition to perform an experiment where the only variable was $\mathrm{Mg}$. This could be done by performing a $\mathrm{Mg}$-repletion experiment where at least the $1 \mathrm{~d}$ delay that accompanies an ordinary pair-feeding experiment could be avoided. Hence, the increase in s-IGF-1 after repletion by absolute pair-feeding can only be attributed to the supply of $\mathrm{Mg}$. There is, not surprisingly, a tendency towards higher growth rates and higher levels of s-IGF-1 in the relative pair-fed group. One would expect that the difference between the two pair-feeding regimens would enlarge if the experiment were prolonged.

The effect of $\mathrm{Mg}$ deficiency on growth was less pronounced than that seen during $\mathrm{Zn}$ deficiency, and this was in accordance with the responses in s-IGF-1.

Our results confirm that specific nutritional deficiency of $\mathrm{Zn}$ is accompanied by reduced serum concentration of IGF-1. Because all earlier studies have been performed with absolute pair-feeding, this effect may be even more pronounced than earlier assumed. In the studies of Öner et al. (1984), Cossack (1984), and Bolze et al. (1987), the s-IGF-1 in rats that were $\mathrm{Zn}$ depleted for $1442 \mathrm{~d}$ was reduced by 36,26 and $21 \%$ respectively compared with absolute pair-fed controls. In the present study, the reduction in s-IGF-1 amounted to $52 \%$ after $7 \mathrm{~d}$ and $60 \%$ after $14 \mathrm{~d}$ in rats on $\mathrm{Zn}$-deficient fodder compared with rats pair-fed by relative pair-feeding.

The GH response during $\mathrm{Zn}$ deficiency was unaltered, indicating that the decrease in sIGF-1 is not mediated through reduced pituitary GH secretion. This is in accordance with the results of Öner et al. (1984) who found that GH treatment in a group of Zn-deficient rats did not increase skeletal growth, and with Prasad et al. (1969) who found that in a group of $\mathrm{Zn}$-deficient rats $\mathrm{GH}$ did not increase weight gain whereas $\mathrm{Zn}$ supplementation restored growth.

It is now generally accepted that the growth-promoting effects of $\mathrm{GH}$ are mediated through the insulin-like growth factors, in particular IGF-1 (Froesch et al. 1985). Serum IGF- 1 is mainly derived from the liver, where it is produced in response to GH (Schwander et al. 1983).

As in $\mathrm{Zn}$ deficiency, the GH response to GRF is not reduced during $\mathrm{Mg}$ deficiency suggesting that the reduction in s-IGF-1 is elicited via a receptor or post-receptor defect. This is in contrast to our earlier observations on potassium-deficient rats where the $G H$ secretory response to GRF was blunted (Flyvbjerg et al. 1991). In the present experiments the $\mathrm{GH}$ response to GRF was not reduced during $\mathrm{Mg}$ or $\mathrm{Zn}$ deficiency indicating that the mechanism involved in growth regulation during these dietary deficiencies is different from that seen in $\mathrm{K}$ deficiency. The $\mathrm{GH}$ peak in the experiment with $\mathrm{Mg}$-deficient animals (Fig. 3) was lower than that in the experiment with the Zn-deficient animals (Fig. 6). This may be because the animals in the first experiment (Fig. 3) were younger than those in the second experiment (Fig. 6).

In the Mg-deficient rats the reduction of s-IGF-1 was not accompanied by a significant reduction of s-insulin, but the $\mathrm{Zn}$-deficient rats had a significant reduction in s-insulin compared with the pair-fed controls although these non-fasted values showed great variability. It was not possible to obtain insulin values after $12 \mathrm{~h}$ fasting because this would depress the s-IGF-1 values of all groups. In the study of Bolze et al. (1987) $\mathrm{Zn}$-deficient rats 
showed a drop in s-insulin. However, this was also seen in the pair-fed rats, indicating that the effect was due to decreased food intake. It cannot, however, be excluded that the reduced s-insulin may play a role in the growth retardation seen during $\mathrm{Zn}$ deficiency.

In diabetic rats with different severity of diabetes, a strong correlation between s-IGF-1 levels and longitudinal growth was found (Binz et al. 1989) indicating that low concentrations of IGF-1 in serum may be the causal factor in the growth retardation. However, it cannot be ruled out that the reduction in s-IGF-1 might be accompanied by reduced concentrations of IGF-1 in tissue. So one could hypothesize that reduced production of serum and peripheral insulin-like growth factors is responsible for the growth retardation seen during $\mathrm{Mg}$ - and $\mathrm{Zn}$-deficient states.

In children with protein-energy malnutrition s-IGF-1 is low, but normal levels may be attained after a relatively short period on a rehabilitation diet (Smith et al. 1989). In addition to the nutritional lack of protein and energy, this condition may be accompanied by $\mathrm{K}$ deficiency (Alleyne, 1970), Mg deficiency (Caddell \& Goddard, 1967) and Zn deficiency (Laditan \& Ette, 1982), and possibly of other micronutrients as well. This may contribute to the grave reduction in s-IGF-1 and the serious growth retardation that is often seen during protein-energy malnutrition. There is now evidence that additional $\mathrm{Zn}$ supplementation of the rehabilitation diet accelerates weight gain (Golden, 1988). In parallel, the inclusion of $\mathrm{Mg}$ in the recovery diet may improve the compensatory growth of children by favouring the complete normalization of s-IGF-1.

This study was supported by grants from DANIDA, Aarhus University Research Council, Aa. Louis-Hansen Memorial Foundation, Nordic Insulin Foundation, the NOVO Foundation and the Danish Diabetes Association. I.D. held a research fellowship from Alfred Benzon's Foundation.

The authors wish to thank Tove Lindahl Andersen, Hanne Mertz, Bente Mortensen, Ebba de Neergård, Kirsten Nyborg and Marianne Stürup-Johansen for technical assistance. Furthermore, they are grateful to Drs L. E. Underwood and J. J. Van Wyk and the National Hormone and Pituitary Program for gifts of the anti-IGF-1 and ingredients for rGH-assay and to A. M. Kappelgaard (Nordisk, Gentofte, DK) for the gift of GRF 40.

Finally, they thank Professor Hans Ørskov for constructive discussion and critical reading of the manuscript.

\section{REFERENCES}

Alleyne, G. A. O. (1970). Studies on total body potassium in malnourished infants. Factors affecting potassium repletion. British Journal of Nutrition 24, 205-212.

Binz, K., Zapf, J. \& Froesch, E. R. (1989). The role of insulin-like growth factor I in growth of diabetic rats. Acta Endocrinologica 121, 628-632.

Bolze, M. S., Reeves, R. D., Lindbeck, F. E. \& Elders, M. J. (1987). Influence of zine on growth, somatomedin, and glycosaminoglycan metabolism in rats. American Journal of Physiology 252, E21-E26.

Caddell, J. L. \& Goddard, D. R. (1967). Studies in protein-calorie malnutrition. I. Chemical evidence for magnesium deficiency. New England Journal of Medicine 276, 533-535.

Cossack, Z. T. (1984). Somatomedin-C in zinc deficiency. Experientia 40, 498-500.

Dørup, I. \& Clausen, T. (1989). Effects of potassium deficiency on growth and protein synthesis in skeletal muscle and the heart of rats. British Journal of Nutrition 62, 269-284.

Dørup, I. \& Clausen, T. (1991). Effects of magnesium and zinc deficiencies on growth and protein synthesis in skcletal muscle and the heart. British Journal of Nutrition 66, 493-504.

Fliesen, T., Maiter, D., Gerard, G., Underwood, L. E., Maes, M. \& Ketelslegers, J.-M. (1989). Reduction of serum insulin-like growth factor I by dietary protein restriction is age dependent. Pediatric Research 26, $415-419$

Flyvbjerg, A., Dørup, I., Everts, M. E. \& Ørskov, H. (1991). Evidence that potassium deficiency induces growth retardation through reduced circulating levels of growth hormone and insulin-like growth factor I. Metabolism 40, 769-775.

Flyvbjerg, A., Frystyk, J., Thorlacius-Ussing, O. \& Ørskov, H. (1989). Somatostatin analogue administration 
prevents increase in kidney somatomedin $\mathrm{C}$ and initial renal growth in diabetic and uninephrectomized rats. Diabetologia 32, 261-265.

Froesch, E. R., Schmid, C., Schwander, J. \& Zapf, J. (1985). Actions of insulin-like growth factors. Annual Reviews of Physiology 47, 443-467.

George, G. A. \& Heaton, F. W. (1978). Effect of magnesium deficiency on energy metabolism and protein synthesis by liver. International Journal of Biochemistry $9,421-425$.

Giugliano, R. \& Millward, D. J. (1984). The effects of severe zinc deficiency on protein turnover in muscle and thymus. British Journal of Nutrition 52, 545-560.

Golden, M. H. N. (1988). The role of individual deficiencies in growth retardation of children as exemplified by zinc and protein. In Linear Growth Retardation in Less Developed Countries. Nestle Nutrition Workshop Series, vol. 14. [J. C. Waterlow, editor]. Vevey: Nestec Ltd/New York: Raven Press.

Handelsman, D. J. , Spaliviero, J. A., Scott, C. D. \& Baxter, R. C. (1987). Hormonal regulation of the peripheral surge of insulin-like growth factor I in the rat. Endocrinology 120, 491-496.

Hunt, B. J. (1971). Age and magnesium deficiency in the rat with emphasis on bone and muscle magnesium. American Journal of Physiology 221, 1809-1817.

Hurley, L. S. (1969). Zinc deficiency in the developing rat. American Journal of Clinical Nutrition 22, $1332-1339$.

Isley, W. L., Underwood, L. E. \& Clemmons, D. R. (1983). Dietary components that regulate serum somatomedin-C concentrations in human. Journal of Clinical Investigation 71, 175-182.

Laditan, A. A. O. \& Ette, S. I. (1982). Plasma zinc and copper levels during the acute phase of protein-energy malnutrition (PEM) and after recovery. Tropical and Geographical Medicine 34, 77-80.

Miller, W. J. (1969). Absorption, tissue distribution, endogenous excretion, and homeostatic control of zinc in ruminants. American Journal of Clinical Nutrition 22, 1323-1331.

O'Leary, M. J., McClain, C. J. \& Hegarty, P. V. J. (1979). Effect of zinc deficiency on the weight, cellularity and zinc concentration of different skeletal muscles in the post-weanling rat. British Journal of Nutrition 42, 487-495.

Öner, G., Bhaumick, B. \& Bala, M. (1984). Effect of zinc deficiency on serum somatomedin levels and skeletal growth in young rats. Endocrinology 114, 1860-1863.

Ørskov, H. \& Seyer-Hansen, K. (1974). Measurement of and correction for incubation damage in radioimmunoassay. European Journal of Clinical Investigation 4, 207-211.

Ørskov, H., Thomsen, A. G. \& Yde, H. (1968). Wick-chromatography for rapid and reliable immunoassay of insulin, glucagon and growth hormone. Nature 219, 193-195.

Pitts, G. C. (1986). Cellular aspects of growth and catch-up growth in the rat: a reevaluation. Growth 50 , $419-436$.

Prasad, A. S., Oberlease, D., Wolf, P. \& Horwitz, T. J. (1969). Effect of growth hormone on nonhypophysectomized zinc-deficient rats. Journal of Laboratory and Clinical Medicine 73, 486-494.

Schwander, J. C., Hauri, C., Zapf, J. \& Froesch, E. R. (1983). Synthesis and secretion of insulin-like growth factor and its binding protein by the perfused rat liver: Dependence on growth hormone status. Endocrinology 113, $297-305$.

Schwartz, R., Woodcock, N. A., Blakely, J. D., Wang, F. L. \& Khairallah, E. A. (1970). Effect of magnesium deficiency in growing rats on synthesis of liver proteins and serum albumin. Journal of Nutrition 100, $123-128$.

Smith, F. I., Taiwo, O. \& Payne-Robinson, H. M. (1989). Plasma somatomedin C in Nigerian malnourished children fed a vegetable protein rehabilitation diet. European Journal of Clinical Nutrition 43, 705-713.

Southon, S., Livesey, G., Gee, J. M. \& Johnson, I. T. (1985). Intestinal cellular proliferation and protein synthesis in zinc-deficient rats. British Journal of Nutrition 53, 595-603.

Takahashi, K., Daughaday, W. H. \& Kipnis, D. M. (1971). Regulation of immunoreactive growth hormone secretion in male rats. Endocrinology 88, 909-917.

Warner, R. G. \& Breuer, L. H. (1972). Nutrient requirements of the laboratory rat. In Nutrient Requirements of Laboratory Animals, 2nd ed., pp. 56-95. Washington, DC: National Academy of Sciences.

Wilkins, P. J., Grey, P. C. \& Dreosti, I. E. (1972). Plasma zinc as an indicator of zinc status in rats. British Journal of Nutrition 27, 113-120.

Williams, R. B. \& Mills, C. F. (1970). The experimental production of zinc deficiency in the rat. British Journal of Nutrition 24, 989-1003.

Winick, M. \& Noble, A. (1966). Cellular response in rats during malnutrition at various ages. Joumal of Nutrition 89, 300-306. 